\title{
You witnessed it. you were part of it, you helped do it. the extermination of negroes
}

Volume 4 Issue 3 - 2015

\section{Opinion}

There is no greater sociopolitical tragedy than the treatment of Negroes today. Negroes have been exterminated out of existence. Negroes are unpersons. "Negro" is a taboo word routinely censored and prohibited from use. What an insult. What a tragedy. What ignorance. It is a total annihilation where a people are never to be allowed, spoken of, or heard from again! I cannot think of a worst treatment for anybody. And it was not done by whites but by blacks.

It all began in the 1960's when Stokley Carmichael proclaimed a self-defining was needed with the use of "black" rather than "Negro." He recognized the power of imitating racists and did so. As "white" had been maliciously and malignantly used, so could "black."

Amazing: As whites were realizing their errors in all this, blacks decided to imitate and continued the craziness of color-based thinking and actions. So blacks became slavers in the worst sense because they now used, as whites had used, color to exalt themselves unfairly, to manipulate the system for themselves unjustly, and to shame and force those not black into unequality and inferiority. Some self-defining: "Black" IS an identity with "white" in the days of slavery. And today such blacks are no better than yesterday's whites because the actions are the same. Then it was "white white white." Now it is "black black black." There is no substantial difference between those who then enslaved by "white" and those who now would enslave by "black." The self-defining is to be no better than the slavers of old while one annihilates Negroes like never before. "If you cannot beat them join them" is the stupid meaning of Stokley Carmichael's selfdefining into "black" instead of "Negro."

Unlike Negroes, blacks seek oppression and feed off of it . . wanting others to help rather than helping oneself. Blacks seek excuses rather than explanations and use victimhood to extort a token human beingness. And "black" is (just like "white" was) used to separate people rather than embrace commonality. "Black" as fad or fetish is as wrong-headed if not as damaging as "white" was; both are used or have been used in the same way.

In fact, black history is a myth. There was no black history before Stokley Carmichael. Black history is actually nothing more than Lemming Leaders since Stokley Carmichael continuing slavery politics by shouting "black" this time instead of "white." Before Stokley Carmichael there was and still is Negro history ... and it was a glorious history of Negroes as dark-skinned individuals proving their humanity, fighting against bigotry as best they could without dehumanizing themselves (even though dehumanized by others), and by tolerating (as necessary) the oppression without seeking it. Negroes knew they were paying the price for a future of one human family.

For five hundred years, Negroes made the effort_ To call it other than Negro history is an insult and an ultimate injustice against those individuals who identified themselves (their self-

\author{
Samuel A Nigro M.D \\ Retired, Assistant Clinical Professor Psychiatry, Case Western \\ Reserve University School of Medicine, USA
}

Correspondence: Dr. Samuel A Nigro M.D., Retired,Assistant Clinical Professor Psychiatry, Case Western Reserve University School of Medicine, 2517 Guilford Road, Cleveland Heights, Ohio 44I I8, USA, Tel 216 932-0575, Email sam@docnigro.com

Received: October 15, 2015 | Published: November 24, 2015

defining, Stokley) as Negroes. Only the worst intellectual criminals would define them out of existence.

For blacks to redefine the past by applying today's standards to the past is an intellectual disgrace and (in the process) a betrayal of all Negroes at the same time.

The ignorant hatred demonstrated by blacks is leveled at Negroes no less than at Caucasians, and this is fundamentally a selfhatred which has abandoned truth and their own historical anchor which IS truth . . . and therefore it will end up going nowhere and be injurious in the long duration. The annihilation of "Negro" is an outrageous self-hatred which is actually a hatred of all mankind.

Negroes survived much and taught much. It cannot be allowed to happen that Negroes are exterminated by blacks or by anyone else. No decent human being can allow that to happen. If that is allowed to happen, we will have willingly participated in the most extensive, complete, and effective ethnic cleansing in the horrible history of humanity. An entire group of people will have been exterminated from history. What they did will have been stolen from them and claimed by others "black." They will have been renamed by words they did not choose or know, and what they themselves called themselves will be forgotten, prohibited, or mocked.

It is difficult to think of a worse way to treat somebody.

This is genocide. You witnessed it. You have been part of it. You helped do it, actively or passively.

\section{Acknowledgments}

None.

\section{Conflicts of interest}

None.

\section{Funding}

None. 